Article

\title{
Efficient and stable Ru(III)-choline chloride catalyst system with low Ru content for non-mercury acetylene hydrochlorination
}

\author{
Hang $\mathrm{Li}^{\mathrm{a}}$, Botao $\mathrm{Wu}^{\text {a }}$, Jianhui Wang b ${ }^{\mathrm{b}}$, Fumin Wang a,*, Xubin Zhang a,\#, Gang Wang c, Haichao Li ${ }^{\mathrm{c}}$ \\ a School of Chemical Engineering \& Technology, Collaborative Innovation Center of Chemical Science and Chemical Engineering (Tianjin), Tianjin \\ University, Tianjin 300350, China \\ b Department of Chemistry, School of Science, Tianjin University, Tianjin 300072, China \\ c College of Chemistry and Chemical Engineering, Qinghai Nationalities University, Xining 810007, Qinghai, China
}

\section{A R T I C L E I N F O}

\section{Article history:}

Received 16 May 2018

Accepted 6 June 2018

Published 5 November 2018

\section{Keywords:}

Acetylene hydrochlorination

Catalytic activity

Heterogeneous catalysis

Ionic complex

Ruthenium

\begin{abstract}
A B S T R A C T
Herein, we report an excellent, supported $\mathrm{Ru}(\mathrm{III})-\mathrm{ChCl} / \mathrm{AC}$ catalyst with lower $\mathrm{Ru}$ content, where the ionic complex $\mathrm{ChRuCl}_{4}$ serves as the active component for acetylene hydrochlorination. The prepared heterogeneous $\mathrm{Ru}-10 \% \mathrm{ChCl} / \mathrm{AC}$ catalyst shows excellent activity and long-term stability. In this system, $\mathrm{ChCl}$ provides an environment for the $\mathrm{ChRuCl}_{4}$ to be stabilized as $\mathrm{Ru}(\mathrm{III})$, thus suppressing the reduction of the active species and the aggregation of ruthenium species during the reaction. The interaction between reactants and catalyst species was investigated by catalyst characterizations in combination with DFT calculations to disclose the effect of the $\mathrm{ChRuCl}_{4}$ complex and $\mathrm{ChCl}$ on the catalytic performance. This inexpensive, efficient, and long-term catalyst is a competitive candidate for application in the hydrochlorination industry.
\end{abstract}

(C) 2018, Dalian Institute of Chemical Physics, Chinese Academy of Sciences. Published by Elsevier B.V. All rights reserved.

\section{Introduction}

Vinyl chloride monomer (VCM) is a significant commodity chemical with over a million tons being consumed annually for the increasing global production of polyvinyl chloride (PVC) [1]. Industrial VCM can be manufactured by the oxychlorination of ethylene derived from petroleum, or hydrochlorination of acetylene obtained from coal [2]. The coal-based acetylene route is economically advantageous relative to ethylene oxychlorination because of the rich coal reserves in China. Currently, the acetylene hydrochlorination reaction is typically catalyzed by carbon-supported mercuric chloride. However, mercury-based catalysts exhibit deactivation, which leads to a decrease in activity, and volatilization of mercury, which is a significant problem due to mercury's toxic nature. For example, it was reported that about $8 \times 10^{5} \mathrm{~kg}$ of $\mathrm{HgCl}_{2}$ is consumed annually for PVC production in China, with over $25 \% \mathrm{HgCl}_{2}$ failing to be recycled, thereby leading to the leakage of more than $2 \times$ $10^{5} \mathrm{~kg}$ of $\mathrm{HgCl}_{2}$ during the reaction [3-5]. To reduce the consumption of $\mathrm{Hg}$ in the PVC industry by 2020, China has been one of the signatories of the Minamata Convention on mercury [6]. Therefore, the development of Hg-free green catalysts for the acetylene hydrochlorination reaction has become imperative for a sustainable PVC industry in China.

Over the past two decades, many researchers have screened numerous non-mercury metal chloride catalysts such as

\footnotetext{
* Corresponding author. Tel/Fax: +86-22-27890041; E-mail: wangfumin@tju.edu.cn

\# Corresponding author. Tel/Fax: +86-22-27890041; E-mail: tjzxb@tju.edu.cn

This work was supported by the National Basic Research Program of China (2012CB720302) and the National Key R\&D Program of China (2016YFF0102503.
}

DOI: 10.1016/S1872-2067(18)63121-3 | http://www.sciencedirect.com/science/journal/18722067 | Chin. J. Catal., Vol. 39, No. 11, November 2018 
$\mathrm{Au}(\mathrm{III}), \mathrm{Pt}(\mathrm{II}), \mathrm{Pd}(\mathrm{II}), \mathrm{Ru}(\mathrm{III}), \mathrm{Rh}(\mathrm{III}), \mathrm{Cu}(\mathrm{II})$, and $\mathrm{Bi}(\mathrm{III})$, and many of these were found to be active for acetylene hydrochlorination [7-13]. The Au-based catalysts developed by Hutchings's group [14] have already been successfully tested in a pilot evaluation for over $3000 \mathrm{~h}$, and the catalyst conversion was suppressed by $85 \%$ throughout the operation of the pilot plant. Zhao et al. [15] reported that the less toxic and recyclable organic aqua regia (OAR) can be used as a greener alternative solvent to conventional aqua regia to activate $\mathrm{Au} / \mathrm{AC}$ catalysts in the acetylene hydrochlorination reaction. However, the scarce resources and high cost are becoming the obstacles limiting the large-scale application of $\mathrm{Au}$ catalysts, and prompt researchers to develop other efficient and cost-effective non-mercury catalysts for acetylene hydrochlorination [16,17]. In recent years, Ru-based catalysts have been considered as alternatives to Au-based catalysts due to their high activity, low price, and environmental friendliness, and a wide variety of methods have been adopted to improve the activity and stability of Ru-based catalysts. In 2013, Zhang et al. [18] reported that the $\mathrm{Ru}_{1} \mathrm{Co}_{3} / \mathrm{SAC}$ catalyst showed more than $95 \%$ acetylene conversion within $48 \mathrm{~h}$ under the conditions of $170{ }^{\circ} \mathrm{C}$ and $\mathrm{C}_{2} \mathrm{H}_{2}$ GHSV (gas hourly space velocity) of $180 \mathrm{~h}^{-1}$. In 2015, Li et al. [19] found that Ru metal supported inside carbon nanotubes showed good catalytic performance. Hou et al. [20] observed that a nitrogen-doped $\mathrm{Ru} / \mathrm{SAC}-\mathrm{N} 700$ catalyst exhibited better catalytic activity and stability for acetylene hydrochlorination, and that the $\mathrm{N}$-dopants effectively reduce the coke deposition on the catalyst. Subsequently, Zhang et al. [21] revealed that the acetylene conversion reached $99 \%$ with the $\mathrm{Ru}_{1} \mathrm{Co}(\mathrm{III})_{3} \mathrm{Cu}(\mathrm{II})_{1}$ catalyst at $170{ }^{\circ} \mathrm{C}$ and a GHSV $\left(\mathrm{C}_{2} \mathrm{H}_{2}\right)$ of $180 \mathrm{~h}^{-1}$, and that no obvious decline was observed in $500 \mathrm{~h}$ under the reaction conditions of $170{ }^{\circ} \mathrm{C}$ and a GHSV $\left(\mathrm{C}_{2} \mathrm{H}_{2}\right)$ of $90 \mathrm{~h}^{-1}$.

As mentioned above, considering the practical applications, the long-term stability of metal chloride catalysts is still a great challenge in developing non-mercury catalysts. These metal salt catalysts inevitably encounter the problem of deactivation because the metallic cations are easily reduced to zero-valent states by the reductive $\mathrm{C}_{2} \mathrm{H}_{2}$ gas during the reaction, which results in the rapid deactivation of the reaction [22-24]. Additionally, Nkosi and other researchers have found that the coking effect which originates from the adsorbed vinyl chloride monomer or oligomerization of the acetylene and vinyl chloride is another problem for the catalysts [25-27]. It should also be pointed out that the $\mathrm{Ru}$ content in most of the ruthenium-based catalysts mentioned above is $1 \mathrm{wt} \%$, which is still too high for their application. Thus, the enhancement of activity and lifetime of Ru-based catalysts is still a challenge in the acetylene hydrochlorination reaction.

Recently, ionic liquids (ILs) have attracted significant attention for application in the acetylene hydrochlorination reaction regardless of whether the system is homogeneous or heterogeneous [25,28,29]. Xing et al. [28] reported that the active and stable metal nanoparticles (NPs) in a surfactant IL system showed excellent performance for the gas-liquid acetylene hydrochlorination reaction. Zhao et al. [29] was the first to describe a supported gold imidazolium-based IL ([Prmim]Cl) complex catalyst for gas-phase acetylene hydrochlorination in a fixed-bed reactor, which demonstrated excellent catalytic activity and long-term stability. Shang et al. [25] reported that the efficient Ru@TPPB catalyst showed excellent activity and stability. It was found that TPPB provides a solvent environment for active ruthenium species such as $\mathrm{RuCl}_{3}$ and $\mathrm{RuO}_{2}$. However, the toxicology of both imidazolium-based and quaternary phosphonium salt ILs have not yet been fully studied. Also, the high cost of these ionic liquids limits their applications in the PVC industry [30]. Choline chloride as an analog of ionic liquids has been used as the catalyst for Diels-Alder reactions and Fischer indole annulation reactions [31,32]. In addition, choline chloride is more inexpensive, non-toxic, and easier to store than most ionic liquids because choline is a naturally occurring bio-compatible compound [33]. To our knowledge, this cleaner analog of ionic liquids has not been used in acetylene hydrochlorination reactions.

Herein, a highly efficient $\mathrm{Ru}(\mathrm{III})-\mathrm{ChCl}$ catalyst system with lower $\mathrm{Ru}$ content, which remains highly active and stable in a continuous gas-solid process for acetylene hydrochlorination, was successfully developed. The catalysts are composed of the active ruthenium complex $\left(\mathrm{ChRuCl}_{4}\right)$ stabilized as the $\mathrm{Ru}(\mathrm{III})$ form and excessive choline chloride $(\mathrm{ChCl})$ on the carbon support. In this paper, the mechanism of the catalytic reaction in this $\mathrm{Ru}(\mathrm{III})-\mathrm{ChCl} / \mathrm{AC}$ system is discussed in detail via catalyst characterization combined with computational study.

\section{Experimental}

\subsection{Material}

Coconut-activated carbon (20-40 mesh) was purchased from Fujian Xinsen Activated Carbon Industry Science and Technology Co., Ltd. $\mathrm{RuCl}_{3}$ (purity 99\%) was purchased from Sigma-Aldrich. Choline chloride $(\mathrm{ChCl})$ was purchased from J\&K Scientific Ltd. $\mathrm{C}_{2} \mathrm{H}_{2}$ (gas, 99.99\%) and $\mathrm{HCl}$ (gas, 99.99\%) were purchased from Tianjin Hexagonal Industrial Gases Distribution Co., Ltd. All reagents and materials were directly used without further purification.

\subsection{Catalyst preparation}

The supported $\mathrm{Ru}(\mathrm{III})-\mathrm{ChCl} / \mathrm{AC}$ catalysts were prepared using an incipient wetness impregnation technique. Activated carbon (AC) was used as the solid porous support for this $\mathrm{Ru}(\mathrm{III})-\mathrm{ChCl}$ system. Firstly, $\mathrm{RuCl}_{3}$ precursor ( $0.02 \mathrm{~g}$ ) and $\mathrm{ChCl}$ $(0.05 \mathrm{~g})$ were dissolved in deionized water $(10 \mathrm{~mL})$ under stirring until complete dissolution. Then, the activated carbon $(5.0$ g) was added to the solution with agitated stirring, followed by ultrasonication in an ultrasonic bath for $10 \mathrm{~min}$. Subsequently, the system was aged at $60{ }^{\circ} \mathrm{C}$ for $10 \mathrm{~h}$ and dried at $80{ }^{\circ} \mathrm{C}$ in a vacuum oven for $12 \mathrm{~h}$ to obtain the catalysts, denoted as $\mathrm{Ru}-1 \% \mathrm{ChCl} / \mathrm{AC}$, where $1 \%$ represents the mass percentage of $\mathrm{ChCl}$ in the activated carbon support. The Ru content in all samples was fixed at $0.2 \mathrm{wt} \%$. Similar methods were applied to prepare catalysts labeled as $\mathrm{Ru}-5 \% \mathrm{ChCl} / \mathrm{AC}, \mathrm{Ru}-10 \% \mathrm{ChCl} / \mathrm{AC}$, and $\mathrm{Ru}-20 \% \mathrm{ChCl} / \mathrm{AC}$ with different contents of $\mathrm{ChCl}$. Furthermore, the same process was adopted to prepare the 
$10 \% \mathrm{ChCl} / \mathrm{AC}$ and the monometallic $\mathrm{Ru} / \mathrm{AC}$.

Due to the low solubility of the complex in ethanol, for the sake of separation, the ruthenium complex $\left(\mathrm{ChRuCl}_{4}\right)$ was synthesized by dissolving $\mathrm{RuCl}_{3}$ in a ChCl-ethanol solution for better separation, where the mole ratio of $\mathrm{ChCl}$ to $\mathrm{RuCl}_{3}$ is $2: 1$, resulting in the rapid formation of a maroon-colored solid, followed by stirring for $10 \mathrm{~min}$, aging for $12 \mathrm{~h}$ at $60^{\circ} \mathrm{C}$ and finally, evaporating the solvents.

The carbon-supported $\mathrm{ChRuCl}_{4} / \mathrm{AC}$ catalyst was also prepared using an incipient wetness impregnation technique. Firstly, $\mathrm{ChRuCl}_{4}(0.03 \mathrm{~g})$ was dissolved in deionized water (10 $\mathrm{mL}$ ), and carbon (5.0 g) was added to the solution under agitated stirring, followed by ultrasonication in an ultrasonic bath for $10 \mathrm{~min}$. Thereafter, the system was maintained at $60{ }^{\circ} \mathrm{C}$ for $10 \mathrm{~h}$ and dried at $80^{\circ} \mathrm{C}$ in a vacuum oven for $12 \mathrm{~h}$ to obtain the catalysts. Notably, the active ruthenium complex exists as $\mathrm{ChRuCl}_{4}$ in the $\mathrm{Ru}(\mathrm{III})-\mathrm{ChCl} / \mathrm{AC}$ catalyst system, which is further discussed below.

\subsection{Catalytic performance evaluations}

The catalyst performance in the hydrochlorination reaction was evaluated in a fixed-bed micro-reactor (10 $\mathrm{mm}$ diameter). The temperature of the reactor was measured by a temperature controller (CKW-1100). The experimental setup for the continuous reaction is presented in Fig. S1.

Firstly, nitrogen was fed through a filter into the heated reactor containing $5 \mathrm{~mL}$ catalysts corresponding to the catalyst $(0.9 \mathrm{~g})$ before the reaction in order to remove trace impurities. Hydrogen chloride was fed into the reactor using a calibrated mass flow controller for $40 \mathrm{~min}$ in the initial reaction. Then, acetylene was fed into the reactor to ensure a $V_{\mathrm{HCl}} / V_{\mathrm{C} 2 \mathrm{H} 2} \mathrm{vol}-$ ume ratio of $1.15 / 1$ to obtain a GHSV $\left(\mathrm{C}_{2} \mathrm{H}_{2}\right)$ of $900 \mathrm{~h}^{-1}\left(\mathrm{C}_{2} \mathrm{H}_{2}\right.$ : $75.0 \mathrm{~mL} / \mathrm{min}, \mathrm{HCl}: 86.3 \mathrm{~mL} / \mathrm{min})$ or $540 \mathrm{~h}^{-1}\left(\mathrm{C}_{2} \mathrm{H}_{2}: 45 \mathrm{~mL} / \mathrm{min}\right.$, HCl: $51.8 \mathrm{~mL} / \mathrm{min}$ ) [4,9,34]. The effluent gas mixture was passed through $\mathrm{NaOH}$ solution to remove the unreacted hydrogen chloride and then analyzed by gas chromatography (GC; Beifen-Ruili SP-3420A) to determine the acetylene conversion and VCM selectivity values. The conversion of acetylene $\left(X_{\mathrm{A}}\right)$ and the selectivity to VCM $\left(S_{\mathrm{VC}}\right)$ were calculated according to the formula below using $N_{\mathrm{A} 0}$ as the volume fraction of acetylene in the feed gas, $N_{\mathrm{A}}$ as the remaining acetylene, and $N_{\mathrm{Vc}}$ as the volume fraction of the vinyl chloride gas in the product mixture gas, with all these values determined by GC analysis.

$$
\begin{gathered}
X_{\mathrm{A}}(\%)=\left(1-\frac{N_{\mathrm{A}}}{N_{\mathrm{A} 0}}\right) \times 100 \\
S_{\mathrm{VC}}(\%)=\frac{N_{\mathrm{VC}}}{1-N_{\mathrm{A}}} \times 100
\end{gathered}
$$

\subsection{Characterization}

Nitrogen adsorption/desorption isotherms were evaluated at $-196{ }^{\circ} \mathrm{C}$ with a Bjbuilder analyzer. The catalysts were degassed at $200{ }^{\circ} \mathrm{C}$ for $6 \mathrm{~h}$, and then measured using liquid nitrogen adsorption at $-196^{\circ} \mathrm{C}$. TEM analysis was performed using a transmission electron microscope (TEM; Tecnai G2 F30) with an accelerating voltage of $300 \mathrm{kV}$. The catalyst samples were dispersed in ethanol and then deposited onto $\mathrm{Cu}$ grids covered with Holey carbon film. The morphology of the catalysts was characterized by SEM with a Philips XL-30 scanning electron microscope. Thermogravimetric analysis (TGA) was performed on a Metler Toledo TGA/DSC instrument in the temperature range from 20 to $900{ }^{\circ} \mathrm{C}$ at the rate of $5{ }^{\circ} \mathrm{C} / \mathrm{min}$ with an air flow of $10 \mathrm{~mL} / \mathrm{min}$. X-ray photoelectron spectroscopy (XPS) was performed using a PHI-5000 Versaprobe II System to determine the surface chemical compositions. The binding energy was calibrated to the $\mathrm{C} 1 \mathrm{~s}$ level of $284.8 \mathrm{eV}$, and the step size of the XPS spectra was $0.1 \mathrm{eV}$. The raw spectra were fitted using the XPSPEAK 4.1 fitting program adopting mixed Gaussian (80\%)-Lorentzian (20\%) functions. Temperature-programmed desorption (TPD) experiments were performed on a Quantachrome Instruments AMI-90 to analyze the adsorption capacity of the catalysts for reactants and products. For the HCl-TPD and $\mathrm{C}_{2} \mathrm{H}_{2}$-TPD profiles, the catalysts first adsorbed under $\mathrm{HCl}$ and $\mathrm{C}_{2} \mathrm{H}_{2}$ atmospheres for $4 \mathrm{~h}$ at $170{ }^{\circ} \mathrm{C}$, respectively. Next, the catalysts were kept in a pure helium atmosphere for $30 \mathrm{~min}$ and the profiles were recorded in the temperature range of $50-700{ }^{\circ} \mathrm{C}$ at a heating rate of $10{ }^{\circ} \mathrm{C} / \mathrm{min}$. CO-TPD was conducted in this instrument, with the samples pretreated at $400{ }^{\circ} \mathrm{C}$ under $\mathrm{H}_{2} / \mathrm{Ar}$ atmosphere, and thereafter, the $\mathrm{CO}$ uptake profile measured using a TCD detector. X-ray diffraction (XRD) measurements were conducted using a D8 Focus X-ray diffractometer with monochromatized $\mathrm{Cu} K_{\alpha}$ radiation $(\lambda=1.5406 \AA)$ operating in the $2 \theta$ scan range $30^{\circ}$ to $75^{\circ}$.

The total ruthenium content in the catalysts was determined by inductively coupled plasma mass spectrometry (ICP-MS) with a PerkinElmer ELAN DRC-e. In order to measure the $\mathrm{Ru}$ content, the catalysts were calcined at $600{ }^{\circ} \mathrm{C}$ for $2 \mathrm{~h}$, and the rest was dissolved in the mixed acid containing $20 \mathrm{~mL}$ $\mathrm{HCl}, 5 \mathrm{~mL} \mathrm{HNO}_{3}$, and $0.5 \mathrm{~mL} \mathrm{HF}$ to form an aqueous solution. The electrospray mass spectra (ESI-MS) of the active ruthenium complex were recorded on a micrOTOF-Q II instrument (Bruker Daltonics, Billerica, MA, USA) using water as the solvent. Fourier transform infrared spectroscopy (FTIR) was performed on a Bruker VERTEX 70 FT-IR spectrophotometer with a DTGS detector (UV-2550, Japan).

\subsection{Computational details}

All calculations were carried out using Gaussian 09 package at the gas phase. The B3LYP functional combined with the LanL2dz basis set and effective core potential were used for $\mathrm{Ru}$, and the 6-31G(d,p) basis set was employed for other atoms in geometry optimization of all stable point and transition states [35-40]. Frequency calculations were performed at this level with a temperature of $170{ }^{\circ} \mathrm{C}$, wherein the frequency correction factors were used for thermal corrections to Gibbs free energy [41]. Natural bond orbital (NBO) analysis was also performed at the same level [42]. Single-point electronic energy calculations were performed by using the M06 functional combined with the mixed basis set of def2-TZVP for Ru and 6-311+G (3df,2pd) for other atoms, and an ultra-fine integration grid was employed, containing a DFT-D3 correction to describe the dispersion effects [43-45]. The computed structures were il- 
lustrated using CYL View [46]. The figure of wavefunction analysis was prepared by Multiwfn and VMD $[47,48]$.

\section{Results and discussion}

\subsection{Characterization of the $\mathrm{ChRuCl}_{4}$ complex}

The $\mathrm{Ru}(\mathrm{III})-\mathrm{ChCl} / \mathrm{AC}$ catalyst system consists of ruthenium species stabilized in the cationic form by the formation of the $\mathrm{ChRuCl}_{4}$ complex. ESI-MS characterization using water as the solvent was conducted to confirm the synthesized $\mathrm{ChRuCl}_{4}$ complex as an ionic complex, which contains $\mathrm{RuCl}_{4}^{-}$and $\left[\mathrm{C}_{5} \mathrm{H}_{14} \mathrm{NO}\right]^{+}$(negative mode ESI-MS found: $M \mathrm{r} / z=241.77$, 243.77, 245.77; calcd. for $\mathrm{RuCl}_{4}{ }^{-}$242.87. positive mode ESI-MS found: $\mathrm{Mr} / z=104.11$; calcd for $\mathrm{C}_{5} \mathrm{H}_{14} \mathrm{NO}^{+} 104.17$, as shown in Fig. 1). The nature of the obtained $\mathrm{ChRuCl}_{4}$ complex was characterized by FT-IR (Fig. S2) as well as UV-Vis (Fig. S3). From these characterizations, the formation of tetra-coordinated $\mathrm{RuCl}_{4}{ }^{-}$via a Lewis acid-base reaction was confirmed. A similar behavior was also observed for metal chlorides such as $\mathrm{FeCl}_{3}$, $\mathrm{ZnCl}_{2}$, and $\mathrm{AlCl}_{3}$ in the $\mathrm{ChCl}$ system [49].

\subsection{Catalytic performance of Ru(III)-ChCl/AC for acetylene hydrochlorination}

To provide a preliminary evaluation of different catalysts, their catalytic performance was evaluated in a fixed-bed reactor at $170{ }^{\circ} \mathrm{C}$ and high $\mathrm{C}_{2} \mathrm{H}_{2}$ GHSV of $900 \mathrm{~h}^{-1}$. Fig. 2 shows the catalytic performance of the $\mathrm{Ru}-10 \% \mathrm{ChCl} / \mathrm{AC}$ catalyst and the corresponding $\mathrm{Ru} / \mathrm{AC}, \mathrm{AC}$, and $10 \% \mathrm{ChCl} / \mathrm{AC}$ catalysts for comparison. It should be noted that the Ru content in all catalysts was fixed at $0.2 \mathrm{wt} \%$. The $\mathrm{Ru} / \mathrm{AC}$ catalyst showed a lower catalytic activity and poor stability with an acetylene conversion of $9.0 \%$ observed after $25 \mathrm{~h}$ of reaction, while both activity and stability were significantly increased for the $\mathrm{Ru}-10 \% \mathrm{ChCl} / \mathrm{AC}$ catalyst, which exhibited approximately $87.5 \%$ acetylene conversion. It should be noted that acetylene conversion values for the AC support and $10 \% \mathrm{ChCl} / \mathrm{AC}$ were only $6.8 \%$ and $5.2 \%$, respectively, suggesting a negligible contribution from $\mathrm{ChCl}$ to
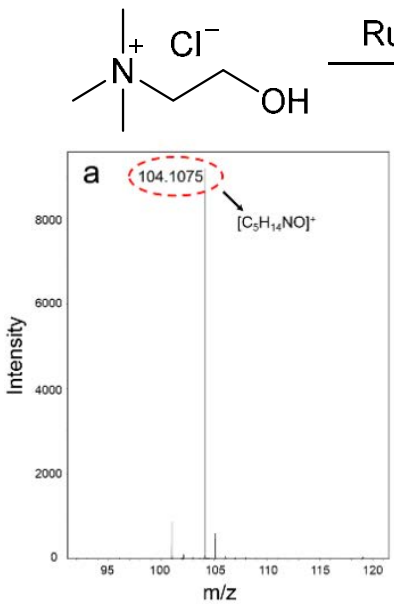
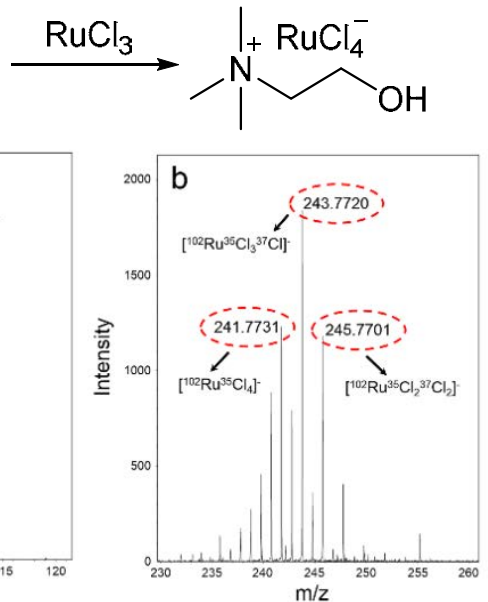

Fig. 1. ESI-MS spectra of (a) $\mathrm{C}_{5} \mathrm{H}_{14} \mathrm{NO}^{+}$(positive ion mode) and (b) $\mathrm{RuCl}_{4}^{-}$(negative ion mode).
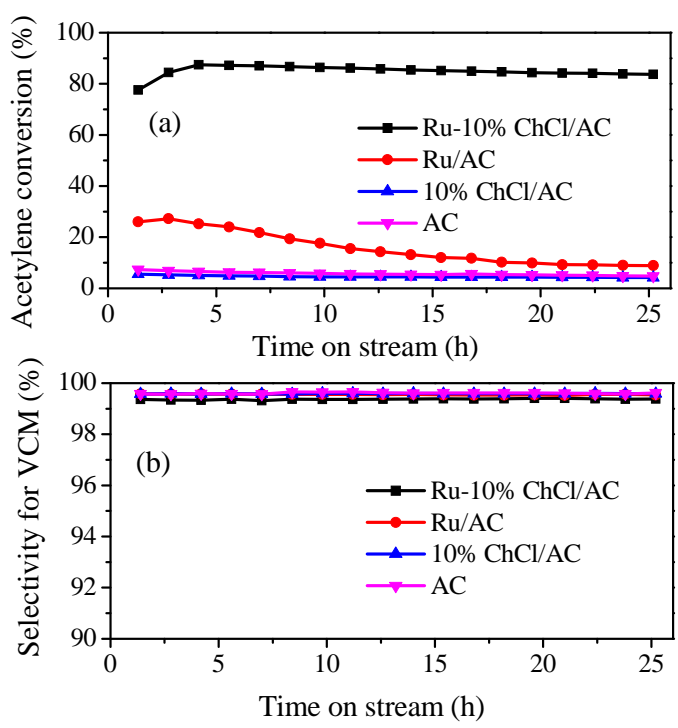

Fig. 2. Conversion of acetylene (a) and selectivity for VCM (b) in the acetylene hydrochlorination reaction for $0.2 \mathrm{wt} \% \mathrm{Ru}$ catalysts over $\mathrm{Ru}-10 \% \mathrm{ChCl} / \mathrm{AC}, \mathrm{Ru} / \mathrm{AC}, 10 \% \mathrm{ChCl} / \mathrm{AC}$, and $\mathrm{AC}$ catalysts. Reaction conditions: $T=170{ }^{\circ} \mathrm{C}$, GHSV $\left(\mathrm{C}_{2} \mathrm{H}_{2}\right)=900 \mathrm{~h}^{-1}$, and $V_{\mathrm{HCl}} / V_{\mathrm{C} 2 \mathrm{H} 2}=1.15$.

the high activity of the $\mathrm{Ru}-10 \% \mathrm{ChCl} / \mathrm{AC}$ catalyst. Meanwhile, all prepared Ru-based catalysts demonstrated more than $99.3 \%$ VCM selectivity with only traces of byproducts.

Furthermore, systematic experiments were carried out to investigate the optimal ratio between $\mathrm{Ru}$ and $\mathrm{ChCl}$, with the results shown in Fig. 3. The $\mathrm{ChRuCl}_{4} / \mathrm{AC}$ catalyst was also synthesized for comparison in order to investigate the catalytic activity of the active ruthenium complex in the catalysts. Remarkably, acetylene conversion reached nearly $99.3 \%$ for the $\mathrm{ChRuCl}_{4} / \mathrm{AC}$ catalyst in a short period of time even at the high
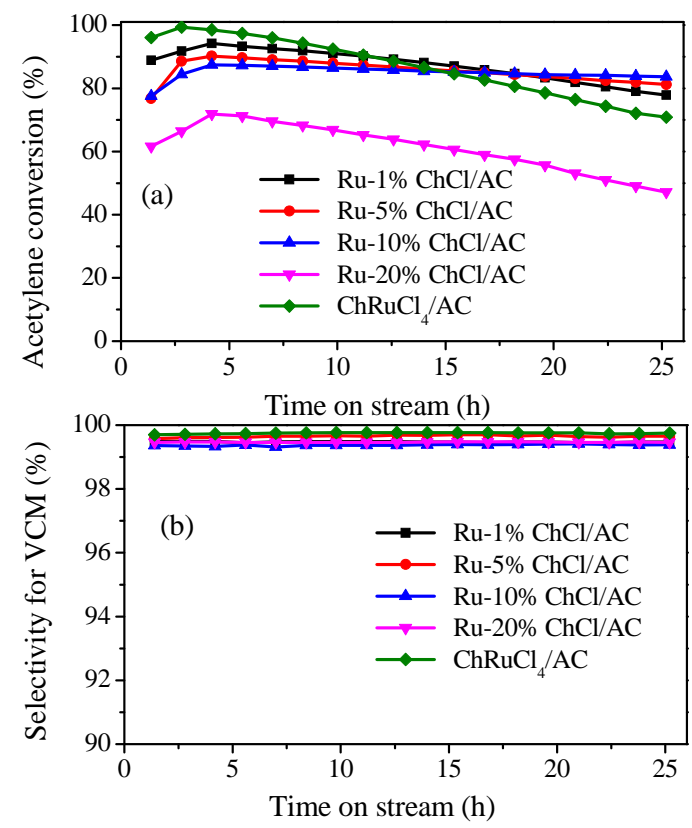

Fig. 3. Conversion of acetylene (a) and selectivity for VCM (b) in the acetylene hydrochlorination reaction for $0.2 \mathrm{wt} \% \mathrm{Ru}$ catalysts with different $\mathrm{ChCl}$ contents. Reaction conditions: $T=170{ }^{\circ} \mathrm{C}, \mathrm{GHSV}\left(\mathrm{C}_{2} \mathrm{H}_{2}\right)=$ $900 \mathrm{~h}^{-1}$, and $V_{\mathrm{HCl}} / V_{\mathrm{C} 2 \mathrm{H} 2}=1.15$. 
GHSV of $\mathrm{C}_{2} \mathrm{H}_{2}\left(900 \mathrm{~h}^{-1}\right)$. The high activity of the $\mathrm{ChRuCl}_{4} / \mathrm{AC}$ catalyst may be due to the enrichment of the active $\mathrm{ChRuCl}_{4}$ complex on the surface of the support. Therefore, the $\mathrm{ChRuCl}_{4}$ complex was identified as the active component in the $\mathrm{Ru}(\mathrm{III})-\mathrm{ChCl} / \mathrm{AC}$ catalyst system. For the $\mathrm{Ru}-x \mathrm{ChCl} / \mathrm{AC}$ catalysts where $x$ represents the weight percentage of $\mathrm{ChCl}$ in the activated carbon support, it can be seen that neither an insufficient nor excessive content of $\mathrm{ChCl}$ in the catalysts led to good catalytic activity and stability. The $\mathrm{Ru}-10 \% \mathrm{ChCl} / \mathrm{AC}$ catalyst showed optimum catalytic activity and excellent stability. We also calculated the TOF value to demonstrate the catalytic properties of the Ru-based catalysts, and the TOF value of $\mathrm{Ru}-10 \% \mathrm{ChCl} / \mathrm{AC}$ is about $40.7 \mathrm{~min}^{-1}$, which makes it one of the most efficient catalytic materials based on TOF (detailed information is shown in Table S1, S2 and Fig. S4). It is worthwhile mentioning that the reaction was performed at lower $\mathrm{C}_{2} \mathrm{H}_{2}$ conversion when calculating the TOF value in order to eliminate the heat or mass transfer effect. The higher initial activity with low $\mathrm{ChCl}$ loading might be due to the higher concentration of the active $\mathrm{Ru}$ complex species at the interface of the solid support. The catalysts with a lower $\mathrm{ChCl}(1 \%$ and $5 \%)$ content had a relatively high initial acetylene conversion but showed rapid deactivation compared with that of the $\mathrm{Ru}-10 \% \mathrm{ChCl} / \mathrm{AC}$ catalyst. This may be caused by the deficiency of $\mathrm{ChCl}$ in the catalyst system, which cannot provide adequate protection for the active $\mathrm{ChRuCl}_{4}$ complex. On the other hand, the blockage of pores in the carbon support by excessive $\mathrm{ChCl}$ leads to the low activity and poor stability of the $\mathrm{Ru}-20 \% \mathrm{ChCl} / \mathrm{AC}$ catalyst, as observed in the SEM image (Fig. S5(d)) and pore structure parameter characterization (Table S3 and Fig. S6).

In addition, thermal stability evaluation of $\mathrm{ChCl}$ was conducted using TG analysis. The TG results imply that decomposition occurs around $300{ }^{\circ} \mathrm{C} \mathrm{(Fig.} \mathrm{S7),} \mathrm{which} \mathrm{is} 130{ }^{\circ} \mathrm{C}$ higher than the reaction temperature, indicating that $\mathrm{ChCl}$ is thermally stable under the reaction conditions. To confirm this excellent performance, the stability test was performed at a high GHSV $\left(\mathrm{C}_{2} \mathrm{H}_{2}\right)$ of $540 \mathrm{~h}^{-1}$ as a function of reaction time at high but not complete conversion in order to truly monitor stability. The results in Figure S8 show that acetylene conversion over the $\mathrm{Ru}-10 \% \mathrm{ChCl} / \mathrm{AC}$ catalyst decreases by $18.4 \%$ from $92.2 \%$ to $75.2 \%$ within $150 \mathrm{~h}$, and the selectivity to VCM is maintained at more than $99.5 \%$ for $150 \mathrm{~h}$, indicating that the $\mathrm{Ru}-10 \% \mathrm{ChCl} / \mathrm{AC}$ catalyst system exhibits high catalytic activity and stability despite low Ru content and shows great potential for industrial applications.

\subsection{Effect of ChCl on $\mathrm{Ru}(\mathrm{III})-\mathrm{ChCl} / \mathrm{AC}$ in acetylene hydrochlorination}

\subsubsection{Valence change in the active component}

XPS spectra were measured to determine the valence states of the ruthenium species in the fresh and used Ru-based catalysts. Deconvolution of the $\mathrm{Ru} 3 p$ profile was used to distinguish the ruthenium species because $\mathrm{Ru} 3 d$ signals overlap with C $1 s$ signals [50,51]. Fig. 4 shows the XPS spectra of the fresh and used $\mathrm{Ru} / \mathrm{AC}$ catalysts and $\mathrm{Ru}-10 \% \mathrm{ChCl} / \mathrm{AC}$ catalysts.

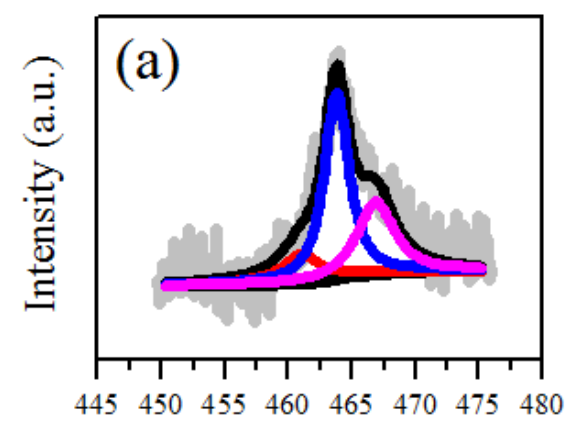

Binding energy $(\mathrm{eV})$

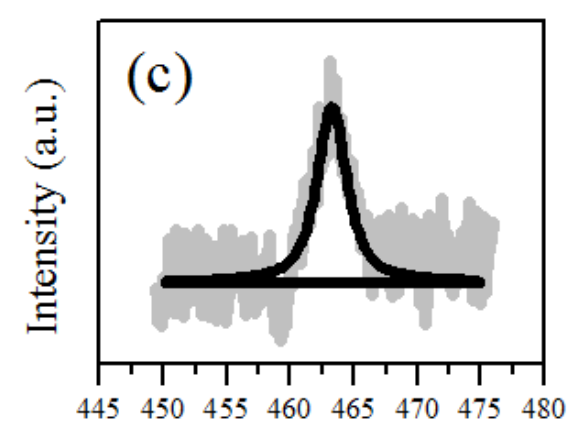

Binding energy $(\mathrm{eV})$

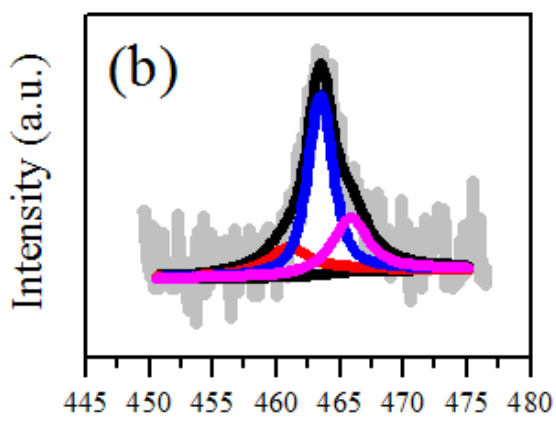

Binding energy $(\mathrm{eV})$

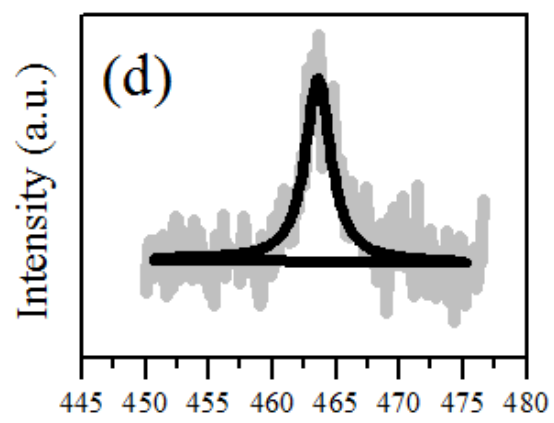

Binding energy $(\mathrm{eV})$

Fig. 4. XPS spectra of Ru $3 p$ for the fresh and used catalysts. (a) Fresh Ru/AC, (b) used Ru/AC, (c) fresh Ru-10\%ChCl/AC, (d) used Ru-10\%ChCl/AC. Ru content 0.2 wt\%. 


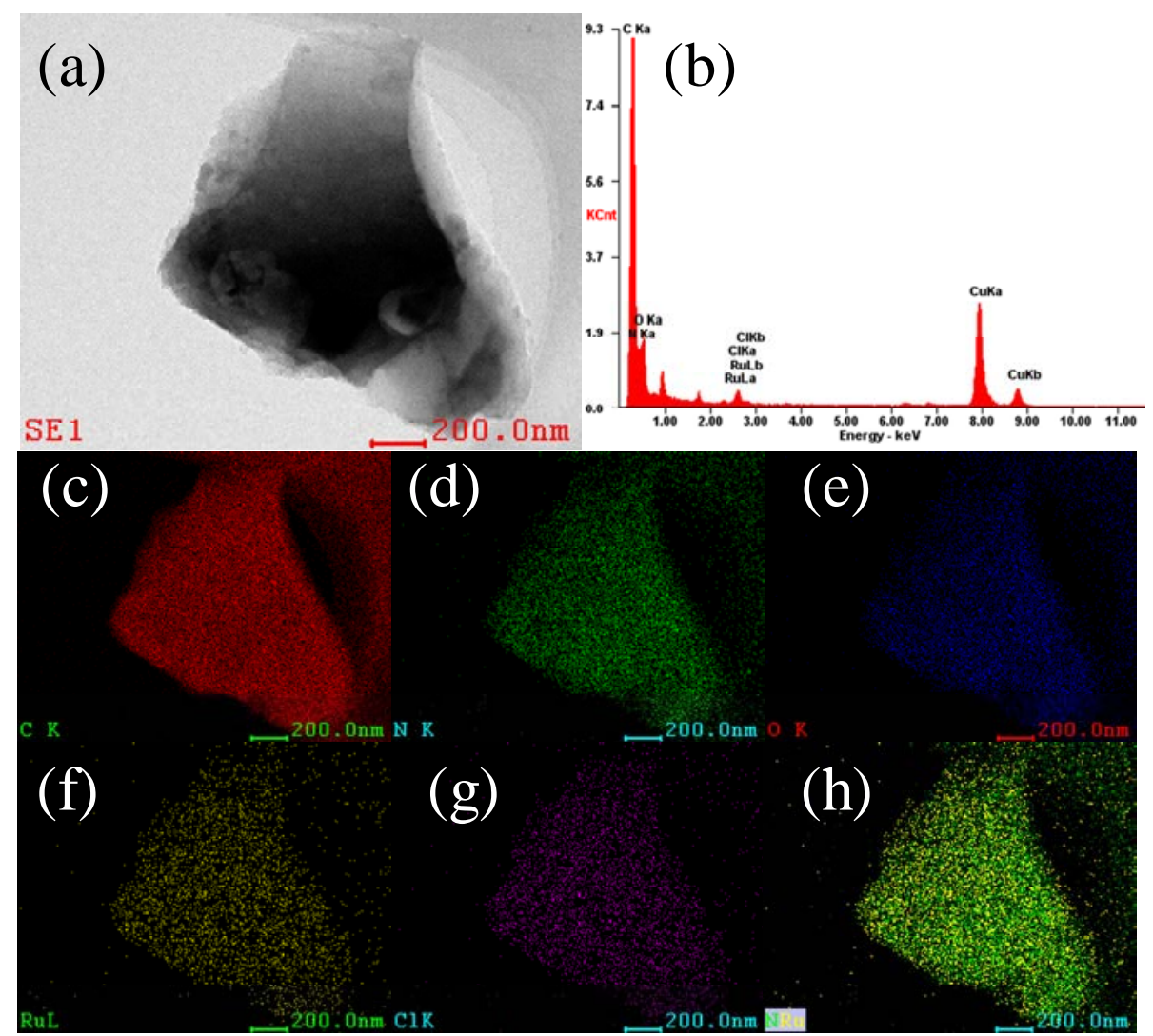

Fig. 5. STEM image (a), EDX analysis (b) and elemental mapping images (c-h) of the fresh $\mathrm{Ru}-10 \% \mathrm{ChCl} / \mathrm{AC}$ catalyst.

For the fresh $\mathrm{Ru} / \mathrm{AC}$ catalyst, there are more than one ruthenium species present, such as the dominant $\mathrm{Ru}(\mathrm{III})(463.3 \pm 0.3$ $\mathrm{eV}), \mathrm{Ru}(>\mathrm{IV})(466.5 \pm 0.3 \mathrm{eV})$, and metallic $\mathrm{Ru}(0)(461.4 \pm 0.4$ $\mathrm{eV}[21,52,53]$. The binding energies and relative contents are listed in Table S4, and are consistent with the observations in the literature $[10,16,20,54]$. In contrast, there is only one strong peak of $\mathrm{Ru}(\mathrm{III})$ in the spectrum of the fresh $\mathrm{Ru}-10 \% \mathrm{ChCl} / \mathrm{AC}$ catalyst, shown in Fig. 4(c), indicating that the active $\mathrm{ChRuCl}_{4}$ complex is in the +3 valence state in the catalyst system and the $\mathrm{Ru}$ exists in the $\mathrm{Ru}(\mathrm{III})$ form due to the formation of the stable $\mathrm{ChRuCl}_{4}$ complex. However, after $25 \mathrm{~h}$ of reaction, compared with that of the fresh $\mathrm{Ru} / \mathrm{AC}$ catalyst, the relative content of high-valence ruthenium species gradually decreased in the used $\mathrm{Ru} / \mathrm{AC}$ catalyst (Table S4), and the activity decreased accordingly [16]. However, as seen in Fig. 4(b), the Ru(III) peak shows no obvious change in the used $\mathrm{Ru}-10 \% \mathrm{ChCl} / \mathrm{AC}$ catalyst. It has been reported that acetylene, being a reductive gas, reduces the metal species in the course of the reaction and thereby causes the rapid deactivation of the catalysts [55]. This demonstrates that the addition of $\mathrm{ChCl}$ in $\mathrm{RuCl}_{3}$, resulting in the formation of the active $\mathrm{ChRuCl}_{4}$ complex, can effectively suppress reduction by acetylene gas, and thus maintain its activity during acetylene hydrochlorination.

\subsubsection{Catalyst sintering}

It is well-known that the aggregation of the metal nanoparticles during the reaction leads to the rapid deactivation of the catalysts [56]. To observe the change in the morphology of the catalysts before and after the reaction, TEM characterization was used to provide detailed images of the catalysts. The scanning transmission electron microscopy (STEM) image accompanied by the energy dispersive X-ray spectroscopy (EDS)
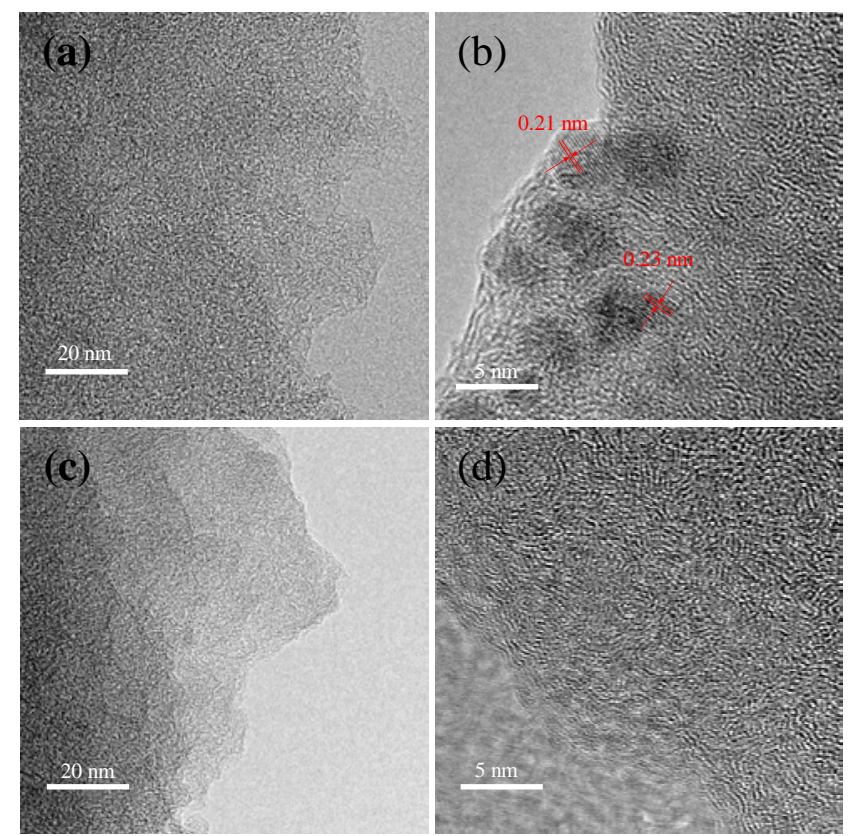

Fig. 6. TEM images of Ru-based catalysts. (a) Fresh Ru/AC, (b) used $\mathrm{Ru} / \mathrm{AC}$, (c) fresh $\mathrm{Ru}-10 \% \mathrm{ChCl} / \mathrm{AC}$, (d) used $\mathrm{Ru}-10 \% \mathrm{ChCl} / \mathrm{AC}$. Ru content $0.2 \mathrm{wt} \%$. 
Table 1

Coke deposition on the catalyst samples.

\begin{tabular}{lc}
\hline Sample & Amount of coke deposition (\%) \\
\hline $\mathrm{Ru} / \mathrm{AC}$ & 8.9 \\
$\mathrm{Ru}-1 \% \mathrm{ChCl} / \mathrm{AC}$ & 7.9 \\
$\mathrm{Ru}-5 \% \mathrm{ChCl} / \mathrm{AC}$ & 5.6 \\
$\mathrm{Ru}-10 \% \mathrm{ChCl} / \mathrm{AC}$ & 2.4 \\
$\mathrm{Ru}-20 \% \mathrm{ChCl} / \mathrm{AC}$ & 1.1 \\
\hline
\end{tabular}

spectra suggest the presence of Ru elements, as well as heteroatoms originated from $\mathrm{ChCl}$, such as $\mathrm{N}, \mathrm{O}$, and $\mathrm{Cl}$, in the fresh $\mathrm{Ru}-10 \% \mathrm{ChCl} / \mathrm{AC}$ catalyst sample. It can also be concluded that most of the ruthenium compounds were homogenously dispersed on the catalyst materials since crystalline nanoparticles were not observed by elemental mapping with STEM/EDS spectroscopy (Fig. 5). This is similar to results reported previously for Au catalysts prepared with a similar method [55,57].

Fig. 6 shows the TEM images of the used $\mathrm{Ru} / \mathrm{AC}$ and $\mathrm{Ru}-10 \% \mathrm{ChCl} / \mathrm{AC}$ catalysts. Ru nanoparticles were detected in the used Ru/AC catalyst, as observed in Fig. 6(b). Two characteristic lattice fringes with lattice spacings of 0.21 and $0.23 \mathrm{~nm}$ are found in the HRTEM images, which can be attributed to the (101) and (100) crystal faces of $\mathrm{Ru}$, respectively [10]. The appearance of metallic Ru nanoparticles indicates the sintering of the metal on the catalyst during the reaction and is also a reason for the rapid activity decrease of the $\mathrm{Ru} / \mathrm{AC}$ catalyst. Interestingly, the Ru nanoparticles were not seen after the reaction, and the STEM mapping results show that the $\mathrm{Ru}, \mathrm{N}, \mathrm{O}$, and $\mathrm{Cl}$ elements were still well separated and dispersed throughout the carbon support (Fig. S9). X-ray diffraction (XRD) analysis also showed that no characteristic peak of ruthenium species is detected in the fresh Ru-based catalysts (Fig. S10), which indicates that most ruthenium species are dispersed well or the concentration of $\mathrm{Ru}$ is too low to be detected by XRD. These findings confirm that the addition of $\mathrm{ChCl}$ inhibits the sintering of the Ru catalyst during the acetylene hydrochlorination reaction. Identical conclusions were also obtained in studies where the presence of ILs stabilized the oxidized metal complex, and thus prevented the agglomeration of the active species [56].

\subsubsection{Coke deposition and loss of the active component}

Coke deposits may originate from $\mathrm{C}_{2} \mathrm{H}_{2}$, VCM, or their oligomers, because $\mathrm{C}_{2} \mathrm{H}_{2}$ and VCM may oligomerize during the reaction [58]. This would cover the active sites of the catalysts and hinder the access of reactants. Thermogravimetric (TG) analysis was performed to evaluate the degree of carbon deposition on the surface of the Ru-based catalysts. For the monometallic $\mathrm{Ru} / \mathrm{AC}$ catalyst, the slight mass loss before $150{ }^{\circ} \mathrm{C}$ is mainly due to the evaporation of adsorbed water, and the rapid mass loss above $400{ }^{\circ} \mathrm{C}$ is caused by the burning of the carbon support. Therefore, it is the mass loss from 150 to $400{ }^{\circ} \mathrm{C}$ that indicates that the variation on the catalyst is potentially caused by coke deposition during the hydrochlorination reaction $[27,59]$. In the case of the fresh $\mathrm{Ru} / \mathrm{AC}$ catalyst, the mass loss in the temperature range of $150-400{ }^{\circ} \mathrm{C}$ is $1.3 \%$, while it is $10.2 \%$ for the used catalyst. Thus, the amount of coke deposition is $8.9 \%$ for the $\mathrm{Ru} / \mathrm{AC}$ catalyst after a $25 \mathrm{~h}$ reaction. The coke depositions on the catalysts after a $25 \mathrm{~h}$ reaction, determined by the above method, are shown in Fig. S11, and the amounts of coke deposition on the used catalysts are summarized in Table 1. In the $\mathrm{Ru}(\mathrm{III})-\mathrm{ChCl} / \mathrm{AC}$ catalysts, the amount of coke deposition is obviously reduced compared with that of the $\mathrm{Ru} / \mathrm{AC}$ catalyst, and it decreases with increasing $\mathrm{ChCl}$ content. As listed in Table 1, the $\mathrm{Ru}-20 \% \mathrm{ChCl} / \mathrm{AC}$ catalyst has the least coke deposition of $1.1 \%$ but also shows a poor stability, which may be explained by the excessive $\mathrm{ChCl}$ on the catalyst, which partially covers the active sites of the $\mathrm{ChRuCl}_{4}$ complex. This proves that $\mathrm{ChCl}$ efficiently inhibits the coke deposition, and thereby positively affects the stability of the catalyst in this case.

Additionally, inductively coupled plasma mass spectrometry (ICP-MS) was conducted to confirm the total Ru content of the fresh and used catalysts (Table 2). It can be seen that the $\mathrm{Ru}$ content of all the catalyst samples was consistent with the calculated amount, indicating that only a small amount of Ru was lost during the reaction and calcination processes. In addition, the elemental composition of the catalysts measured by XPS is listed in Table 2 . The used $\mathrm{Ru}-10 \% \mathrm{ChCl} / \mathrm{AC}$ catalyst system is thermally stable because no drastic change in $\mathrm{N}$ content was observed during the reaction, which is also in good agreement with the TG experiment (Fig. S7) discussed above.

\subsubsection{Adsorption properties of the reactants and product}

TPD profiles were obtained to study the adsorption properties of the reactants and product on different catalysts. Fig. 7(a)-(c) show the TPD profiles of $\mathrm{HCl}, \mathrm{C}_{2} \mathrm{H}_{2}$, and VCM, respectively, of the $\mathrm{Ru} / \mathrm{AC}, \mathrm{Ru}-10 \% \mathrm{ChCl} / \mathrm{AC}, 10 \% \mathrm{ChCl} / \mathrm{AC}$, and $\mathrm{ChRuCl}_{4} / \mathrm{AC}$ samples. The peak area in the TPD profiles reflects the adsorption capacity of active species, and the desorption temperature is correlated with the strength of the adsorbed species [60].

In the He-TPD profile, the strong peak observed at approximately $260{ }^{\circ} \mathrm{C}$ is related to the decomposition of $\mathrm{ChCl}$ under the test environment. As observed in Fig. 7(a), the $\mathrm{HCl}$ desorption peak in $\mathrm{Ru}-10 \% \mathrm{ChCl} / \mathrm{AC}$ moves to a higher temperature and the desorption area becomes significantly larger than that of the $\mathrm{Ru} / \mathrm{AC}$ catalyst, indicating an increase in $\mathrm{HCl}$ adsorption in the $\mathrm{Ru}-10 \% \mathrm{ChCl} / \mathrm{AC}$ catalyst. Similarly, $\mathrm{ChRuCl}_{4} / \mathrm{AC}$ and $10 \% \mathrm{ChCl} / \mathrm{AC}$ also exhibit strong $\mathrm{HCl}$ adsorption, showing the

Table 2

Atomic ratios determined by XPS analysis and the Ru contents in the fresh and used catalysts calculated by ICP analysis.

\begin{tabular}{|c|c|c|c|c|c|c|c|}
\hline \multirow{2}{*}{ Sample } & \multicolumn{5}{|c|}{ Surface atomic composition of the catalysts (\%) } & \multirow{2}{*}{$\begin{array}{c}\text { Calculated loading (wt\%) } \\
\mathrm{Ru}\end{array}$} & \multirow{2}{*}{$\begin{array}{c}\text { Actual loading (wt\%) } \\
\mathrm{Ru} \\
\end{array}$} \\
\hline & $\mathrm{C}$ & $\mathrm{N}$ & 0 & $\mathrm{Cl}$ & $\mathrm{Ru}$ & & \\
\hline Fresh $\mathrm{Ru} / \mathrm{AC}$ & 89.88 & - & 9.42 & 0.53 & 0.17 & 0.200 & 0.186 \\
\hline Used $\mathrm{Ru} / \mathrm{AC}$ & 90.60 & - & 8.79 & 0.45 & 0.16 & 0.200 & 0.179 \\
\hline Fresh $\mathrm{Ru}-10 \% \mathrm{ChCl} / \mathrm{AC}$ & 86.79 & 3.44 & 5.58 & 3.97 & 0.22 & 0.200 & 0.180 \\
\hline Used $\mathrm{Ru}-10 \% \mathrm{ChCl} / \mathrm{AC}$ & 87.53 & 3.41 & 4.80 & 4.05 & 0.21 & 0.200 & 0.175 \\
\hline
\end{tabular}



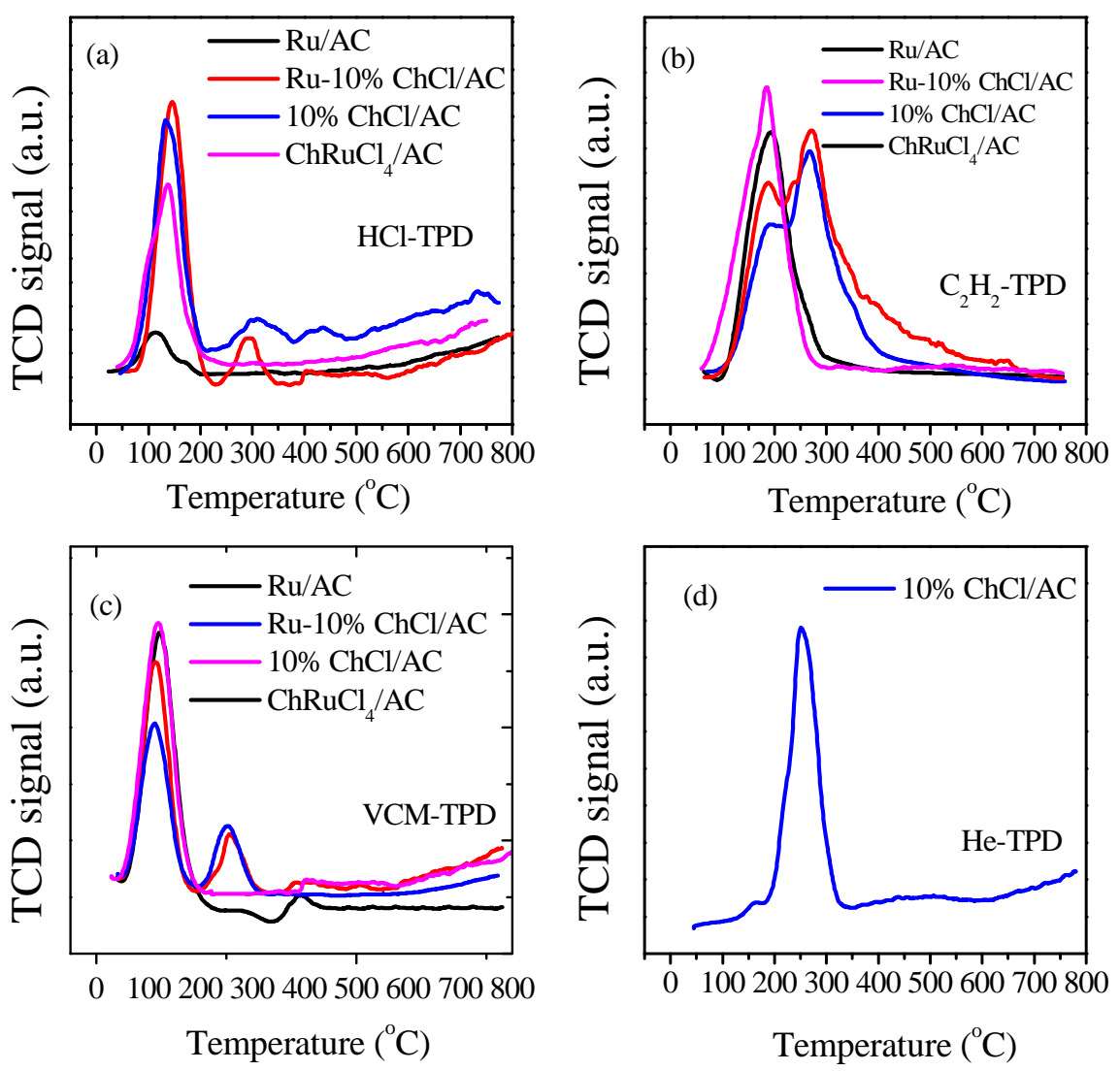

Fig. 7. TPD profiles of the fresh catalysts. (a) HCl-TPD, (b) $\mathrm{C}_{2} \mathrm{H}_{2}-\mathrm{TPD}$, (c) VCM-TPD, (d) He-TPD.

simultaneous contribution of $\mathrm{ChRuCl}_{4}$ and $\mathrm{ChCl}$ species to the increased adsorption of $\mathrm{HCl}$ in this catalyst system. The $\mathrm{C}_{2} \mathrm{H}_{2}$ and VCM-TPD profiles of the $10 \% \mathrm{ChCl} / \mathrm{AC}$ and $\mathrm{Ru}-10 \% \mathrm{ChCl} / \mathrm{AC}$ samples show a smaller adsorption capacity compared with that of the $\mathrm{Ru} / \mathrm{AC}$ catalyst, suggesting that excessive $\mathrm{ChCl}$ reduces, to some extent, the amount of coke deposition. In addition, it is worth noting that although the $\mathrm{ChRuCl}_{4}$ serving as an active component in the catalysts has high reactant $\mathrm{C}_{2} \mathrm{H}_{2}$ adsorption to promote the hydrochlorination reaction, it also increases the probability of coke deposition during the reaction. This may explain why the $\mathrm{ChRuCl}_{4} / \mathrm{AC}$ catalyst shows a relatively rapid deactivation under high $\mathrm{C}_{2} \mathrm{H}_{2}$ GHSV (Fig. 3). Song et al. [61] also proved that the adsorption of $\mathrm{C}_{2} \mathrm{H}_{2}$ is negatively correlated with catalyst stability. Based on the above reports, the favorable adsorption of $\mathrm{HCl}$ and weak adsorption of $\mathrm{C}_{2} \mathrm{H}_{2}$ on the $\mathrm{Ru}-10 \% \mathrm{ChCl} / \mathrm{AC}$ catalyst significantly contribute to the excellent stability of the catalysts. Therefore, sufficient $\mathrm{HCl}$ adsorbed in $\mathrm{Ru}(\mathrm{III})-\mathrm{ChCl} / \mathrm{AC}$ effectively supplements the consumption of reacted $\mathrm{HCl}$, and reduces the possibility of $\mathrm{C}_{2} \mathrm{H}_{2}$ deposition on the carbon support. In conclusion, the deactivation by coking is suppressed under adequate $\mathrm{HCl}$ adsorption during acetylene hydrochlorination.

In order to explain the interaction between reactants $(\mathrm{HCl}$ or $\left.\mathrm{C}_{2} \mathrm{H}_{2}\right)$ and catalyst species $\left(\mathrm{ChCl}\right.$ or $\left.\mathrm{ChRuCl}_{4}\right)$ in the $\mathrm{Ru}(\mathrm{III})-\mathrm{ChCl} / \mathrm{AC}$ catalytic system, we carried out a series of DFT calculations. The $\mathrm{RuCl}_{3}$ molecule was also considered here for comparison. The spontaneity of the adsorption can be investi- gated by its Gibbs free energy change $\left(\Delta G_{\text {add }}\right)$. The $\Delta G_{\text {ad }}$ for $\mathrm{HCl}$

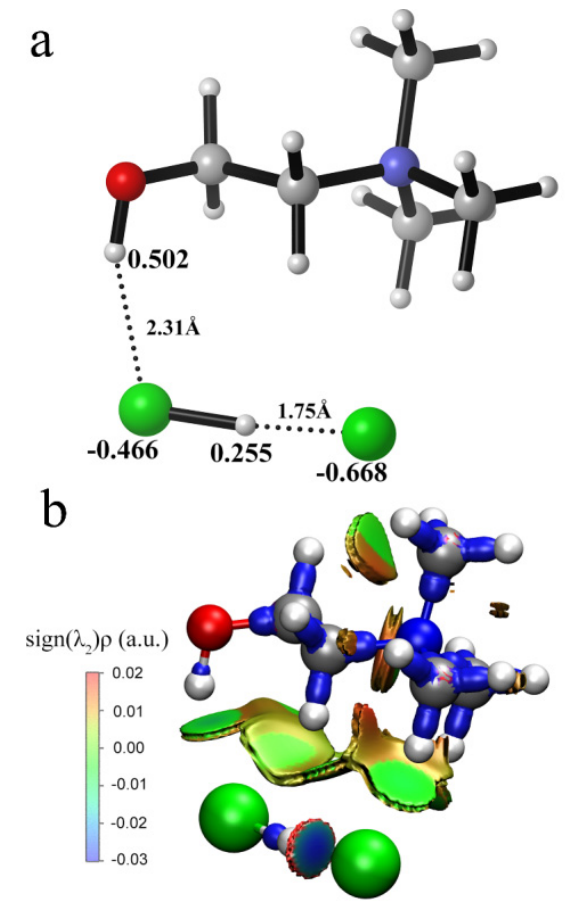

Fig. 8. Stable structure of $\mathrm{HCl}$ adsorbed on $\mathrm{ChCl}$. (a) NPA (natural population analysis) charges; (b) DORI function. Green: chlorine, gray: carbon, silver: hydrogen, dark blue: nitrogen, red: oxygen, similarly hereinafter. 
and $\mathrm{C}_{2} \mathrm{H}_{2}$ on $\mathrm{ChCl}, \mathrm{ChRuCl}_{4}$, and $\mathrm{RuCl}_{3}$ are listed in Table S5. The $\Delta G_{\text {ad }}$ of $\mathrm{C}_{2} \mathrm{H}_{2}$ shows that it can be more easily adsorbed on $\mathrm{ChRuCl}_{4}$ than $\mathrm{RuCl}_{3}$ via $\pi$ coordination (Fig. S14), which leads to a higher acetylene hydrochlorination activity. Additionally, as for $\mathrm{HCl}$ molecule, it should be pointed out that $\mathrm{ChCl}$ and $\mathrm{ChRuCl}_{4}$ species in this catalyst system both have stronger adsorption than $\mathrm{RuCl}_{3}$, which is consistent with the results presented from $\mathrm{HCl}$-TPD characterization. The structure of $\mathrm{HCl}$ adsorbed by $\mathrm{ChCl}$ is mainly relying on hydrogen bonds and van der Waals forces (Fig. 8). A strong hydrogen bond is illustrated by the density overlap regions indicator (DORI) function with $\mathrm{HCl}$ acting as a hydrogen bond donor [62]. An $\mathrm{HCl}$ molecule tends to coordinate with $\mathrm{Ru}(\mathrm{III})$ as a $\mathrm{Cl}^{-}$ligand when it is adsorbed by the $\mathrm{ChRuCl}_{4}$ complex (Fig. 9(a)). The coordination bond order between $\mathrm{Ru}(\mathrm{III})$ and the $\mathrm{Cl}$ of $\mathrm{HCl}$ is 0.476 by Mayer bond order (MBO) calculation [63]. This is consistent with the calculation by the electron localization function (ELF) in Fig. 9 (b), which is used to reveal binding and lone electron pairs in simple molecular systems as well $[64,65]$. Compared with that of the $\mathrm{RuCl}_{3}$ catalyst, this system has an excellent performance in promoting the adsorption of $\mathrm{HCl}$, which significantly improves the catalyst life in acetylene hydrochlorination. Moreover, $\mathrm{ChCl}$ has a negative effect on the adsorption of $\mathrm{C}_{2} \mathrm{H}_{2}$ for $\Delta G_{\text {ad }}>0$, indicating that $\mathrm{ChCl}$ may reduce the aggregation of $\mathrm{C}_{2} \mathrm{H}_{2}$ in the system. Therefore, it is necessary to pretreat and activate the catalyst system with pure $\mathrm{HCl}$ to improve the stability of catalysts, which is consistent with the previous reports $[4,9,34]$.

Table 3 shows the bond lengths, Mayer bond orders, and NPA charges of free and adsorbed HCl. The Mayer bond order

$\mathrm{a}$

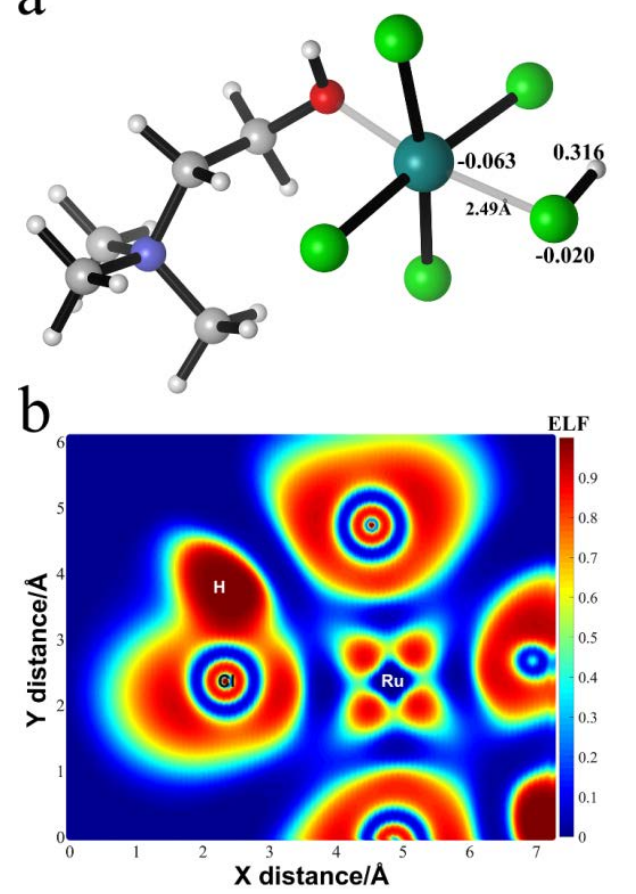

Fig. 9. Stable structure of $\mathrm{HCl}$ nucleophile adsorbed on $\mathrm{ChRuCl}_{4}$. (a) NPA charges; (b) ELF figure. The plane of $\mathrm{Ru}-\mathrm{H}-\mathrm{Cl}$ triatomic molecule was defined as the XOY plane (rectangular plane). Dark green: ruthenium, similarly hereinafter.
Table 3

Comparison of bond length, Mayer bond, and NPA charge of free and adsorbed $\mathrm{HCl}$.

\begin{tabular}{lccc}
\hline Status & $\begin{array}{c}\text { Bond length } \\
(\AA)\end{array}$ & $\begin{array}{c}\text { Mayer bond } \\
\text { order }\end{array}$ & $\begin{array}{c}\text { NPA } \\
\text { charge }\end{array}$ \\
\hline Free $\mathrm{HCl}$ & 1.290 & 0.953 & 0.000 \\
$\mathrm{HCl}$ adsorbed on $\mathrm{ChRuCl}_{4}$ & 1.317 & 0.883 & 0.296 \\
$\mathrm{HCl}$ adsorbed on $\mathrm{ChCl}$ & 1.441 & 0.797 & -0.113 \\
\hline
\end{tabular}

indicates that the covalency of the $\mathrm{H}-\mathrm{Cl}$ bond decreased after adsorption by $\mathrm{ChCl}$ or $\mathrm{ChRuCl}_{4}$. The charge of $\mathrm{HCl}$ reveals that it loses electrons when it coordinates with the $\mathrm{ChRuCl}_{4}$ complex and gains electrons from $\mathrm{ChCl}$ as the hydrogen bond donor. $\mathrm{ChCl}$ and the $\mathrm{ChRuCl}_{4}$ complex simultaneously cause the activation of $\mathrm{HCl}$ in the $\mathrm{Ru}(\mathrm{III})-\mathrm{ChCl} / \mathrm{AC}$ system.

\subsection{Pattern of catalytic mechanism in this system}

The results of this study show that the activation of $\mathrm{HCl}$ is the key to improve the catalyst life in this reaction, which is in agreement with previous studies [7,25,66-68]. However, it remains challenging to enhance the adsorption or activation of $\mathrm{HCl}$ because the $\mathrm{H}-\mathrm{Cl}$ bond is sturdy $(428 \mathrm{~kJ} / \mathrm{mol}$ of bond energy) [69]. In this $\mathrm{Ru}(\mathrm{III})-\mathrm{ChCl} / \mathrm{AC}$ system, the enhanced adsorption of $\mathrm{HCl}$ has been confirmed by both the experimental and computational results above, where the addition of $\mathrm{ChCl}$ and the formation of $\mathrm{ChRuCl}_{4}$ are more effective than traditional $\mathrm{RuCl}_{3}$ catalysts.

The activation of $\mathrm{HCl}$ is to facilitate the heterolytic cleavage process by increasing the molecular polarity. Compared with that of the typical covalent molecular bond before adsorption,
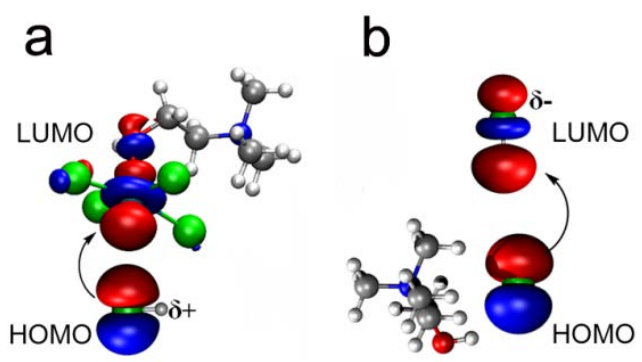

Fig. 10. The interaction between the HOMO of $\mathrm{ChCl}$ and the LUMO of $\mathrm{HCl}(\mathrm{a})$, the LUMO of $\mathrm{ChRuCl}_{4}$ and the HOMO of $\mathrm{HCl}(\mathrm{b})$.

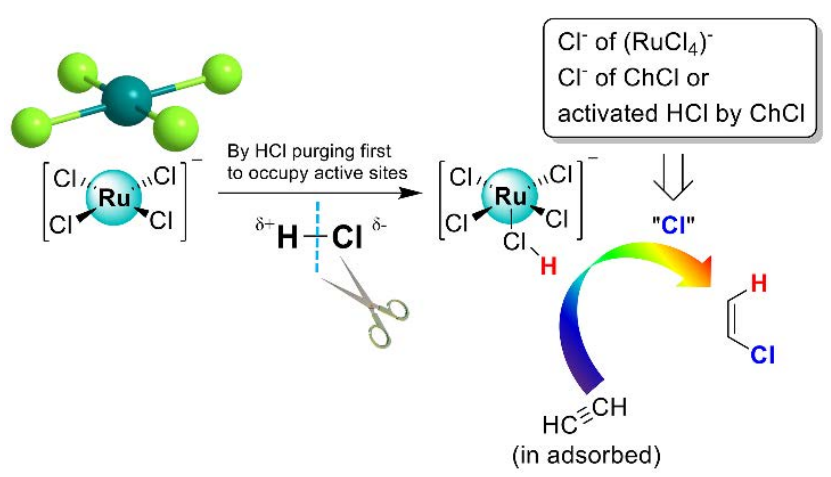

Scheme 1. Proposed catalytic process in this system. 
the activation in this system simultaneously enhances the properties of $\mathrm{H}^{+}$and $\mathrm{Cl}^{-}$in the $\mathrm{HCl}$ molecule according to Table 3. Specifically, electrons transfer from the highest occupied molecular orbital (HOMO) of $\mathrm{HCl}$ to the lowest unoccupied molecular orbital (LUMO) of $\mathrm{ChRuCl}_{4}$. Meanwhile, the LUMO of $\mathrm{HCl}$ accepts electrons of the HOMO of $\mathrm{ChCl}$ (Fig. 10). It is conducive to reducing the energy barrier for the addition of $\mathrm{HCl}$ to $\mathrm{C}_{2} \mathrm{H}_{2}$ molecule. $\mathrm{C}_{2} \mathrm{H}_{2}$ can form a complex with $\mathrm{Ru}(\mathrm{III})$ as a $\pi$ ligand; thus, the $\mathrm{C}-\mathrm{C}$ triple bond is weakened, and can be attacked by nucleophiles or electrophiles [70,71]. A catalytic pathway for the formation of vinyl chloride is proposed in Scheme 1, which shows a synergistic process for this reaction.

As the active site of hydrochlorination reaction, $\mathrm{Ru}(\mathrm{III})$ easily coordinates with the reactant $\mathrm{C}_{2} \mathrm{H}_{2}$ to promote the hydrochlorination reaction, reflecting the high catalytic activity of the catalysts. As has been discussed above, both $\mathrm{ChCl}$ and $\mathrm{ChRuCl}_{4}$ in this catalytic system are critical for the adsorption and activation of $\mathrm{HCl}$ to facilitate hydrochlorination reactions. Owing to the above advantages, this catalyst system greatly promotes the transformation of acetylene to vinyl chloride, and reduces the side effects such as reduction of the metal salts and carbon deposition on the active sites during the reaction. In consequence, this ionic complex is more effective than traditional metal salt catalysts for heterogeneous catalytic hydrochlorination.

\section{Conclusions}

In summary, a novel, efficient, and supported $\mathrm{Ru}(\mathrm{III})-\mathrm{ChCl} / \mathrm{AC}$ catalyst system for acetylene hydrochlorination was successfully developed. An active $\mathrm{ChRuCl}_{4}$ ionic complex was obtained and stabilized in the $\mathrm{Ru}(\mathrm{III})-\mathrm{ChCl} / \mathrm{AC}$ system.
The $\mathrm{Ru}-10 \% \mathrm{ChCl} / \mathrm{AC}$ catalyst realized an acetylene conversion of about $87.5 \%$ and a VCM selectivity surpassing $99.3 \%$ at 170 ${ }^{\circ} \mathrm{C}$ and $\mathrm{C}_{2} \mathrm{H}_{2}$ GHSV of $900 \mathrm{~h}^{-1}$. The catalyst characterization showed that $\mathrm{ChCl}$ provides adequate protection for the active $\mathrm{ChRuCl}_{4}$ to be stabilized in the $\mathrm{Ru}(\mathrm{III})$ form, thus suppressing the reduction of the active $\mathrm{Ru}$ complex as well the particle aggregation during the reaction. Furthermore, both experimental results and theoretical analysis revealed that the coordination of acetylene and the activation of $\mathrm{HCl}$ were simultaneously initiated, and had a significant synergistic effect on the activity and long-term stability of the Ru-based catalysts. Therefore, the excellent performance of this supported $\mathrm{Ru}(\mathrm{III})-\mathrm{ChCl} / \mathrm{AC}$ catalyst might promote further development of efficient and non-mercury green catalysts in the hydrochlorination industry.

\section{References}

[1] X. Wei, H. Shi, W. Qian, G. Luo, Y. Jin, F. Wei, Ind. Eng. Chem. Res., 2008, 48, 128-133.

[2] K. Zhou, W. Wang, Z. Zhao, G. Luo, J. T. Miller, M. S. Wong, F. Wei, ACS Catal., 2014, 4, 3112-3116.

[3] H. Zhang, B. Dai, X. Wang, W. Li, Y. Han, J. Gu, J. Zhang, Green Chem., 2013, 15, 829-836.

[4] M. Conte, A. F. Carley, C. Heirene, D. J. Willock, P. Johnston, A. A. Herzing, C. J. Kiely, G. J. Hutchings, J. Catal, 2007, 250, 231-239.

[5] K. Zhou, J. Jia, C. Li, H. Xu, J. Zhou, G. Luo, F. Wei, Green Chem., 2015, $17,356-364$.

[6] X. Li, X. Pan, X. Bao, J. Energy Chem., 2014, 23, 131-135.

[7] T. V. Krasnyakova, I. V. Zhikharev, R. S. Mitchenko, V. I. Burkhovetski, A. M. Korduban, T. V. Kryshchuk, S. A. Mitchenko, J. Catal., 2012, 288, 33-43.

[8] S. A. Mitchenko, T. V. Krasnyakova, R. S. Mitchenko, A. N. Korduban, J. Mol. Catal. A, 2007, 275, 101-108.

\section{Graphical Abstract}

Chin. J. Catal., 2018, 39: 1770-1781 doi: 10.1016/S1872-2067(18)63121-3

Efficient and stable Ru(III)-choline chloride catalyst system with low Ru content for non-mercury acetylene hydrochlorination

Hang Li, Botao Wu, Jianhui Wang, Fumin Wang *, Xubin Zhang *, Gang Wang, Haichao Li

Tianjin University; Qinghai Nationalities University
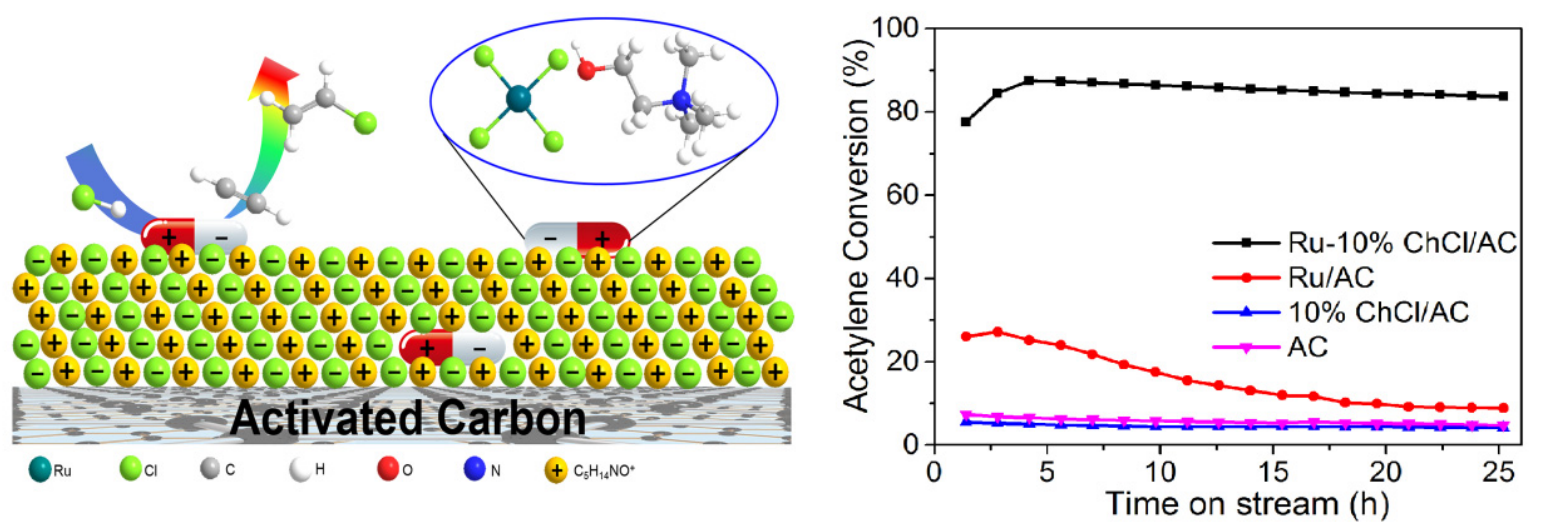

The supported $\mathrm{Ru}(\mathrm{III})-\mathrm{ChCl} / \mathrm{AC}$ catalyst system, where $\mathrm{ChCl}$ provides an environment for the $\mathrm{ChRuCl}_{4}$ to be stabilized as $\mathrm{Ru}(\mathrm{III})$, shows superior activity and stability in acetylene hydrochlorination. 
[9] H. Zhang, B. Dai, W. Li, X. Wang, J. Zhang, M. Zhu, J. Gu, J. Catal., 2014, 316, 141-148.

[10] Y. Pu, J. Zhang, L. Yu, Y. Jin, W. Li, Appl. Catal. A, 2014, 488, 28-36.

[11] H. Li, F. Wang, W. Cai, J. Zhang, X. Zhang, Catal. Sci. Technol., 2015, 5, 5174-5184.

[12] K. Zhou, J. Jia, X. Li, X. Pang, C. Li, J. Zhou, G. Luo, F. Wei, Fuel Process. Technol, 2013, 108, 12-18.

[13] S. A. Panova, G. K. Shestakov, O. N. Temkin, J. Chem. Soc., Chem. Commun., 1994, 977-977.

[14] P. Johnston, N. Carthey, G. J. Hutchings, J. Am. Chem. Soc., 2015, 137, 14548-14557.

[15] J. Zhao, B. Wang, X. Xu, Y. Yu, S. Di, H. Xu, Y. Zhai, H. He, L. Guo, Z. Pan, X. Li, J. Catal., 2017, 350, 149-158.

[16] J. Zhao, S. Gu, X. Xu, T. Zhang, Y. Yu, X. Di, J. Ni, Z. Pan, X. Li, Catal. Sci. Technol., 2016, 6, 3263-3270.

[17] K. C. O'Connell, J. R. Monnier, J. Regalbuto, Appl. Catal. B, 2018, $225,264-272$.

[18] J. Zhang, W. Sheng, C. Guo, W. Li, RSC Adv., 2013, 3, 21062-21068.

[19] G. Li, W. Li, H. Zhang, Y. Pu, M. Sun, J. Zhang, RSC Adv., 2015, 5, 9002-9008.

[20] L. Hou, J. Zhang, Y. Pu, W. Li, RSC Adv., 2016, 6, 18026-18032.

[21] H. Zhang, W. Li, Y. Jin, W. Sheng, M. Hu, X. Wang, J. Zhang, Appl. Catal. B, 2016, 189, 56-64.

[22] M. Conte, A. F. Carley, G. J. Hutchings, Catal. Lett., 2008, 124, 165-167.

[23] M. Conte, C. J. Davies, D. J. Morgan, T. E. Davies, D. J. Elias, A. F. Carley, P. Johnston, G. J. Hutchings, J. Catal., 2013, 297, 128-136.

[24] M. Conte, A. F. Carley, G. Attard, A. A. Herzing, C. J. Kiely, G. J. Hutchings, J. Catal., 2008, 257, 190-198.

[25] S. Shang, W. Zhao, Y. Wang, X. Li, J. Zhang, Y. Han, W. Li, ACS Catal,, 2017, 7, 3510-3520.

[26] H. Xu, K. Zhou, J. Si, C. Li, G. Luo, Catal. Sci. Technol, 2016, 6, 1357-1366.

[27] B. Nkosi, N. J. Coville, G. J. Hutchings, M. D. Adams, J. Friedl, F. E. Wagner, J. Catal., 1991, 128, 366-377.

[28] J. Hu, Q. Yang, L. Yang, Z. Zhang, B. Su, Z. Bao, Q. Ren, H. Xing, S. Dai, ACS Catal., 2015, 5, 6724-6731.

[29] J. Zhao, Y. Yu, X. Xu, S. Di, B. Wang, H. Xu, J. Ni, L. Guo, Z. Pan, X. Li, Appl. Catal. B, 2017, 206, 175-183.

[30] A. Romero, A. Santos, J. Tojo, A. Rodriguez, J. Hazard. Mater., 2008, 151, 268-273.

[31] A. P. Abbott, G. Capper, D. L. Davies, R. K. Rasheed, V. Tambyrajah, Green Chem., 2002, 4, 24-26.

[32] R. Calderon Morales, V. Tambyrajah, P. R. Jenkins, D. L. Davies, A. P. Abbott, Chem. Commun., 2004, 158-159.

[33] A. Zhu, T. Jiang, B. Han, J. Zhang, Y. Xie, X. Ma, Green Chem., 2007, 9 , 169-172.

[34] K. Zhou, B. Li, Q. Zhang, J. Q. Huang, G. L. Tian, J. C. Jia, M. Q. Zhao, G. H. Luo, D. S. Su, F. Wei, ChemSusChem, 2014, 7, 723-728.

[35] M. J. Frisch, G. W. Trucks, H. B. Schlegel, G. E. Scuseria, G. E. Scuseria, M. A. Robb, J. R. Cheeseman, G. Scalmani, V. Barone, B. Mennucci, G. A. Petersson, H. Nakatsuji, M. Caricato, X. Li, H. P. Hratchian, A. F. Izmaylov, J. Bloino, G. Zheng, J. L. Sonnenberg, M. Hada, M. Ehara, K. Toyota, R. Fukuda, J. Hasegawa, M. Ishida, M. Nakajima, Y. Honda, O. Kitao, H. Nakai, T. Vreven, J. A. Montgomery, Jr., J. E. Peralta, F. Ogliaro, M. Bearpark, J. J. Heyd, E. Brothers, K. N. Kudin, V. N. Staroverov, T. Keith, R. Kobayashi, J. Normand, K. Raghavachari, A. Rendell, J. C. Burant, S. S. Iyengar, J. Tomasi, M. Cossi, N. Rega, J. M. Millam, M. Klene, J. E. Knox, J. B. Cross, V.
Bakken, C. Adamo, J. Jaramillo, R. Gomperts, R. E. Stratmann, O. Yazyev, A. J. Austin, R. Cammi, C. Pomelli, J. W. Ochterski, R. L. Martin, K. Morokuma, V. G. Zakrzewski, G. A. Voth, P. Salvador, J. J. Dannenberg, S. Dapprich, A. D. Daniels, O. Farkas, J. B. Foresman, J. V. Ortiz, J. Cioslowski, D. J. Fox, Gaussian 09, Revision C.01; Gaussian Inc.: Wallingford, CT, 2009.

[36] P. C. Hariharan, J. A. Pople, Theor. Chim. Acta., 1973, 28, 213-222.

[37] M. M. Francl, W. J. Pietro, W. J. Hehre, J. S. Binkley, M. S. Gordon, D. J. DeFrees, J. A. Pople, J. Chem. Phys., 1982, 77, 3654-3665.

[38] C. Lee, W. Yang, R. G. Parr, Phys. Rev. B, 1988, 37, 785-789.

[39] P. J. Hay, W. R. Wadt, J. Chem. Phys., 1985, 82, 299-310.

[40] T. H. Dunning Jr, P. J. Hay. Gaussian Basis Sets for Molecular Calculations, Springer, New York, 1977, 1-27.

[41] J. P. Merrick, D. Moran, L. Radom, J. Phys. Chem. A, 2007, 111, 11683-11700.

[42] A. E. Reed, R. B. Weinstock, F. Weinhold, J. Chem. Phys., 1985, 83, 735-746.

[43] A. V. Marenich, C. J. Cramer, D. G. Truhlar, J. Phys. Chem. B, 2009, $113,6378-6396$.

[44] F. Weigend, R. Ahlrichs, Phys. Chem. Chem. Phys., 2005, 7, 3297-3305.

[45] S. Grimme, J. Antony, S. Ehrlich, H. Krieg, J. Chem. Phys., 2010, 132, 154104.

[46] C. Y. C. b. Legault, Legault, C. Y, Université de Sherbrooke, Canada, 2009.

[47] T. Lu, F. Chen, J. Comput. Chem., 2012, 33, 580-592.

[48] W. Humphrey, A. Dalke, K. Schulten, J. Mol. Graphics., 1996, 14, 33-38.

[49] A. P. Abbott, G. Capper, D. L. Davies, R. Rasheed, Inorg. Chem., 2004, 43, 3447-3452.

[50] C. Wagner, A. Naumkin, A. Kraut-Vass, J. Allison, C. Powell, J. Rumble Jr, National Institute of Standards and Technology: Gaithersburg, MD, 2003, 20899.

[51] A. S. Arico, P. Cretı, P. L. Antonucci, J. Cho, H. Kim, V. Antonucci, Electrochim. Acta, 1998, 43, 3719-3729.

[52] R. Chetty, S. Kundu, W. Xia, M. Bron, W. Schuhmann, V. Chirila, W. Brandl, T. Reinecke, M. Muhler, Electrochim. Acta, 2009, 54, 4208-4215.

[53] S. Sharma, Z. Hu, P. Zhang, E. W. McFarland, H. Metiu, J. Catal,, 2011, 278, 297-309.

[54] Y. Jin, G. Li, J. Zhang, Y. Pu, W. Li, RSC Adv., 2015, 5, 37774-37779.

[55] Y. Jia, R. Hu, Q. Zhou, H. Wang, X. Gao, J. Zhang, J. Catal., 2017, 348, 223-232.

[56] Q. Zhang, I. Lee, J. Ge, F. Zaera, Y. Yin, Adv. Funct. Mater., 2010, 20, 2201-2214.

[57] J. Zhao, Y. Yu, X. Xu, S. Di, B. Wang, H. Xu, J. Ni, L. L. Guo, Z. Pan, X. Li, Appl. Catal. B, 2017, 206, 175-183.

[58] X. Li, P. Li, X. Pan, H. Ma, X. Bao, Appl. Catal. B, 2017, 210, 116-120.

[59] D. He, X. Jiao, P. Jiang, J. Wang, B. Q. Xu, Green Chem., 2012, 14, 111-116.

[60] X. Li, M. Zhu, B. Dai, Appl. Catal. B, 2013, 142, 234-240.

[61] S. Chao, Q. Guan, W. Li, J. Catal, 2015, 330, 273-279.

[62] P. de Silva, C. Corminboeuf, J. Chem. Theory Comput., 2014, 10, 3745-3756.

[63] I. Mayer, Chem. Phys. Lett., 1983, 97, 270-274.

[64] A. D. Becke, K. E. Edgecombe, J. Chem. Phys., 1990, 92, 5397-5403.

[65] A. Savin, R. Nesper, S. Wengert, T. F. Fässler, Angew. Chem. Int. Ed., 1997, 36, 1808-1832.

[66] S. A. Mitchenko, T. V. Krasnyakova, R. S. Mitchenko, A. N. Korduban, J. Mol. Catal. A, 2007, 275, 101-108. 
[67] Y. Han, M. Sun, W. Li, J. Zhang, Phys. Chem. Chem. Phys., 2015, 17, 7720-7730.

[68] S. Wang, B. Shen, Q. Song, Catal. Lett., 2010, 134, 102-109.

[69] B. d. B. Darwent, National Bureau of Standards, 1970.
[70] O. Eisenstein, R. Hoffmann, J. Am. Chem. Soc., 1980, 102, 6148-6149.

[71] B. Wang, J. L. Jiang, H. Z. Yu, Y. Fu, Organometallics, 2017, 36, 523-529.

\title{
一种高效稳定的低负载量的氯化-2-羟乙基三甲胺改性钉基催化剂 用于乙炔氢氯化反应
}

\author{
李 航, 吴博韬, 王建辉 ${ }^{\mathrm{b}}$, 王富民 ${ }^{\mathrm{a},{ }^{*}}$, 张旭斌, 击, 王 刚 ${ }^{\mathrm{c}}$, 李海朝 ${ }^{\mathrm{c}}$ \\ ${ }^{\mathrm{a}}$ 天津大学化工学院, 天津化学化工协同创新中心, 天津 300350 \\ $\mathrm{b}$ 天津大学理学院化学系, 天津 300072 \\ c青海民族大学化学化工学院, 青海西宁 810007
}

\begin{abstract}
摘要: 来自煤化工的乙炔氢氯化生产氯乙烯的工艺由于其经济优势成为我国生产PVC的主要路线. 为了降低该工艺中录 触媒催化剂对环境的毒害, 开发高效环保的乙炔氢氯化无录催化剂刻不容缓. 但已有研究表明, 稳定性差和价格高昂成为 制约乙炔氢氯化非录催化剂工业化的瓶颈. 由此, 我们选用价格低廉、催化活性良好的 $\mathrm{RuCl}_{3}$ 作为催化剂的前驱体, 采用浸 渍法制备了低负载量的氯化-2-差乙基三甲胺改性 $\mathrm{RuCl}_{3}$ 的催化剂, 其中活性组分在ESI-MS中观测到是一种离子型配合物, 其阴阳离子分别为 $\mathrm{RuCl}_{4}{ }^{-}$和 $\mathrm{C}_{5} \mathrm{H}_{14} \mathrm{NO}^{+}$. 该催化剂在乙炔氢氯化反应中的测试结果表明, 氯化-2-羟乙基三甲胺的加入可以 显著提高催化活性和稳定性. 通过透射电镜(TEM)和扫描-透射电镜(STEM)表征表明, 该催化体系的活性组分具有良好的 分散性, 季铵盐 $\left[\mathrm{Me}_{3} \mathrm{NCH}_{2} \mathrm{CH}_{2} \mathrm{OH}\right] \mathrm{Cl}$ 不仅与 $\mathrm{RuCl}_{3}$ 形成配合物为活性组分, 其过量时也提供了一个溶剂环境, 能够稳定活性 组分不团聚. 透射电镜和X射线光电子能谱(XPS)结果共同表明, 相比于单一负载的 $\mathrm{RuCl}_{3}$ 催化剂, 该催化体系中 $\mathrm{Ru}$ 物种基 本保持在 +3 氧化态, 不易在制备过程中被氧化或在反应过程中被还原性气体乙炔还原为金属颗粒, 表现出了良好的稳定 性. 程序升温脱附(TPD)结果表明, 氯化-2-差工基三甲胺这一季铵盐的加入能够大幅度提升体系对氯化氢的吸附, 降低体 系对乙炔和产物氯乙烯的吸附, 从而促进乙炔氢氯化反应的进行, 减少体系吸附乙炔或氯乙烯过强导致的积炭现象. 另一 方面, 本工作中采用密度泛函理论方法研究了乙炔氢氯化非录催化剂的性质、催化剂与反应物的吸附和相互作用模式. 其 中吸附能的计算结果表明, 活性组分和季铵盐都能够提升对氯化氢的吸附, 季铵盐还能够抑制体系对乙炔的吸附, 计算结 果与TPD的结果基本一致. 对反应物和催化剂之间的相互作用进行了考察, 发现该体系对氯化氢存在一个协同活化的作 用, 能够促进 $\mathrm{H}-\mathrm{Cl}$ 共价键的异裂, 有利于跨越传统催化剂对氯化氢吸附和活化的障碍. 此外, 该催化体系对乙炔氢氯化过 程也展现了一个协同催化的模式, 为乙炔氢氯化无录非均相催化剂的设计提供了参考.
\end{abstract}

关键词: 乙炔氢氯化; 高活性; 非均相催化; 离子型配合物; 钉

收稿日期: 2018-05-16. 接受日期: 2018-06-06. 出版日期: 2018-11-05.

*通讯联系人. 电话/传真: (022)27890041; 电子信箱: wangfumin@tju.edu.cn

\#通讯联系人. 电话/传真: (022)27890041; 电子信箱: tjzxb@tju.edu.cn

基金来源：国家重点基础研究发展计划(2012CB720302);国家重点研发计划(2016YFF0102503).

本文的电子版全文由Elsevier出版社在ScienceDirect上出版(http://www.sciencedirect.com/science/journal/18722067). 